\title{
ANALISIS PENGELOLAAN DANA DESA DALAM MENINGKATKAN PEREKONOMIAN MASYARAKAT DI KECAMATAN LANGSA KOTA KOTA LANGSA
}

\author{
FAHRUL RIDHA
}

MTs Terpadu Langsa

Fahrulridha90@gmail.com

\begin{abstract}
This research is to find out how to manage village funds and how to improve village governance in improving the economy of the people in Langsa Kota District. This study uses a qualitative descriptive research method. The results of the study found that Village Fund Management has been running effectively, while its allocation has not been $100 \%$ effective. The government's efforts to improve the community economy are by empowering, among others, in the field of infrastructure, empowerment in the general and religious fields. empowerment in the field of infrastructure is by making trenches, roads, making fishing nets or nets and making cakes and embroidery. for community empowerment in general and religious fields. In the general field, the existence of the PKK is realized. In the religious field, it was realized by holding regular recitations and training for tahyiz mayit.
\end{abstract}

Keywords: Management, Village Funds, Improving Community Economy.

\begin{abstract}
Abstrak
Penelitian ini untuk mengetahui bagaimana pengelolaan dana desa dan bagaimana upaya pemerintah desa dalam meningkatkan ekonomi masyarakat di Kecamatan Langsa Kota. Penelitian ini menggunakan metode penelitian deskriptif kualitatif. Hasil penelitian menemukan bahwa PengelolaanDana desa selamaini telah berjalan dengan efektif, walaupun pengalokasiannya belum 100\%efektif.Upaya pemerintah dalam meningkatkan ekonomi masyarakat yaitu dengan melakukan pemberdayaan antara lain di bidang infrastruktur, pemberdayaan di bidang umum dan keagamaan. Pemberdayaan pada bidang infrastruktur adalah dengan adanya pembuatan parit, jalan, pembuatan jaring ikan atau jala dan pembuatan kue serta bordir untuk pemberdayaan masyarakat dalam bidang umum dan keagamaan. Dalam bidang umum diwujudkan dengan adanya PKK. Dalam bidang keagamaan diwujudkan dengan diadakannya pengajian-pengajian rutin dan pelatihan tahyiz mayit.
\end{abstract}

Kata Kunci: Pengelolaan, Dana Desa, Meningkatkan Perekonomian Masyarakat.

\section{Pendahuluan}

Dana desa merupakan dana yang bersumber dari APBN yang diperuntukkan bagi desa, yang ditransfer melalui anggaran belanja daerah Kabupaten. Dana ini digunakan untuk membiayai penyelenggaraan pemerintahan, pelaksanaan pembangunan, pembinaan kemasyarakatan, dan pemberdayaan masyarakat desa. Dana desa dialokasikan dari APBN (Anggaran Pendapatan 
Belanja Negara) berdasarkan pasal 72 ayat 1 huruf b UU No.6 Tahun 2014 tentangDesa.

Berdasarkan pada Peraturan Pemerintah Nomor 60 Tahun 2014 Tentang Dana Desa yang bersumber dari Anggaran Pendapatan dan Belanja Negara, pada ayat pasal yang telah diamandemen pada Peraturan Pemerintah Nomor 168 tahun 2014 ke 11 ayat 2 yang menyatakan bahwa dana desa dialokasikan secara berkeadilan berdasarkan:

a. Alokasidasar, dan

b. Alokasi yang dihitung memperhatikan jumlah penduduk, angka kemiskinan, luas wilayah, dan tingkat kesulitan geografis desa setiap kabupaten/kota. ${ }^{1}$

Dalam UU Nomor 6 Tahun 2014 tentang Desa, yaitu adanya komitmen negara dalam melindungi dan memberdayakan desa agar menjadi kuat, maju, mandiri dan demokratis sehingga dapat menciptakan landasan yang kuat dalam melaksanakan pemerintahan dan pembangunan menuju masyarakat yang adil, makmur dan sejahtera.

Selanjutnya juga diharapkan akan terwujudnya desa yang mandiri dimana:

a. Desa bukan hanya sekedar sebagai obyek penerima manfaat, melainkan sebagai subyek pemberi manfaat bagi warga masyarakat setempat;

b. Sebagai komponen desa mempunyai rasa kebersamaan dan gerakan untuk mengembangkan asset local sebagai sumber penghidupan dan kehidupan bagi warga masyarakat.

c. Desa mempunyai kemampuan menghasilkan dan mencukupi kebutuhan dan kepentingan masyarakat setempat seperti pangan, energi, layanan dasar dan lain-lain.

Sebagai cita-cita jangka panjang, desa mampu menyediakan lapangan pekerjaan, menyediakan sumber-sumber pendapatan bagi masyarakat serta menghasilkan pendapatan asli desa dalam jumlah yang memadai. ${ }^{2}$

Dengan demikian pemerintah desa harus mengambil tindakan dari adanya kebijakan pemerintah pusat yang telah menggulirkan Dana Desa sebagai stimulus pembangunan desa secara adil dan merata dalam pembangunan. Peran pemerintah dalam membangun desa sangat penting dimana pemerintah adalah unit pelaksana utama dalam pembangunan yang akan dibantu oleh beberapa 
lembaga yang lain seperti Badan Permusyawaratan Desa (BPD) dan Lembaga Pemberdayaan Masyarakat (LPM) serta masyarakat desa.

Pada saat ini, alokasi dana desa sangat gencar oleh pemerintah dan daerah untuk dijadikan sebagai sumber awal dari sebuah pendapatan desa, ini berkaitan dengan kebijakan yang diambil oleh pemerintahan desa memanfaatkan dana desa, hal ini melalui berbagai proses sehingga pemanfaat dana desa sesuai dengan pemerintah daerah dan pusat, pemenuhan ini berdampak kepada sektor perekonomian seperti program pemberdayaan masyarakat seperti di desa Meutia yang memprogramkan simpan pinjam perempuan untuk kepentingan masyarakat itu sendiri hal ini tentu berdampak pada sektor perekonomian masyarakat itu sendiri, dan tentunya menjadikan masyarakat lebih berdaya dalam kehidupan masyarakat.

Melihat pada apa yang diamanatkan melalui dana desa ini, program pembangunan dan pemberdayaanlah yang memang menjadi tujuan utamanya, dan peran pemerintah desa dalam hal ini menjadi kunci bagaimana mengalokasikan dana tersebut dengan semestinya, yakni untuk pembangunan dan pemberdayaan.

Pemberdayaan masyarakat pada dasarnya adalah membantu pengembangan manusiawi yang otentik dan integral dari masyarakat yang lemah, miskin, marjinal dan kaum kecil dan memberdayakan kelompok-kelompok masyarakat tersebut secara sosio ekonomis sehingga mereka dapat lebih mandiri dan dapat memenuhi kebutuhan dasar hidup mereka, namun sanggup berperan serta dalam pengembangan masyarakat. ${ }^{3}$

Maka dari itu, pemerintah desa harus kembali pada tugas pokok dan fungsinya sebagai pemimpin desa, yakni diantaranya:

1. Membina kehidupan masyarakat desa.

2. Membina ekonomi desa.

3. Mengordinasikan pembangunan desa secara partisipatif.

4. Melaksanakan wewenang lain sesuai dengan peraturan perundangundangan.

Salah satu pola pendek atau pemberdayaan masyarakat paling efektif dalam rangka peningkatan partisipasi masyarakat adalah merangsang masyarakat untuk mampu mengidentifikasi keinginan dan kebutuhan bekerja secara kooperatif dan menumbuhkan rasa gotong-royong sesama warga desa. 
Dana desa merupakan salah satu alat untuk membantu terlaksananya pemerintahan desa, pembangunan desa, dan pemberdayaan masyarakat dalam upaya meningkatkan perekonomian masyarakat. Dengan adanya dana desa ini, diharapkan agar dapat membantu masyarakat dalam segi kebutuhan, pembangunan sarana dan prasarana, serta dapat mengembangkan potensi ekonomi local yang didasarkan atas kondisi dan potensi desa.

Arthur Lewis membahas proses pembangunan yang terjadi antara daerah kota dan desa, yang mengikut sertakan proses urbanisasi yang terjadi diantara kedua tempat tersebut, sehingga pemerintah Indonesia perlu memberikan kebijakan untuk melakukan pemerataan pembangunan infrastruktur agar tidak terjadi kesenjangan sosial antara masyarakat desa dan kota, hal ini juga dapat membangun Indonesia lebih baik melalui peningkatan perekonomian yang melibatkan partipasi masyarakat secara langsung. ${ }^{4}$

Salah satu pentingnya pemberdayaan masyarakat dalam Islam perlunya diterapkan adalah karena dengan adanya pemberdayaan akan menghasilkan pembangunan yang berkelanjutan. Dengan hal seperti ini maka akan terus dapat memperbaiki taraf hidupnya ke yang lebih baik. Dalam agama Islam memiliki konsep pemberdayaan masyarakat dalam kitab suci yaitu Alquran Q.SAr-Ra'd ayat 11:

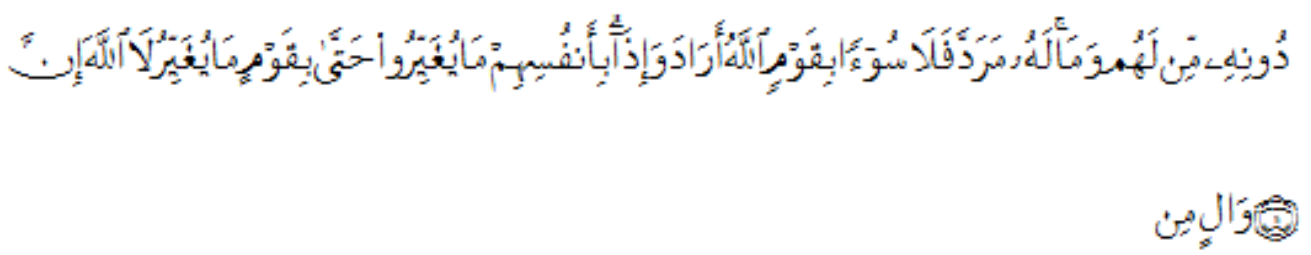

Artinya:"Sesungguhnya Allah tidak merobah Keadaan sesuatu kaum sehingga mereka merobah keadaan yang ada pada diri mereka sendiri. dan apabila Allah menghendaki keburukan terhadap sesuatu kaum, Maka tak ada yang dapat menolaknya". 5

Berdasarkan ayat Ar- Ra'd ayat 11 yang menyebutkan bahwaTuhan tidak akan merubah Keadaan mereka, selama mereka tidak merubah sebab - sebab kemunduran mereka. Sejalan dengan teori pemberdayaan masyarakat yang mana melalui pemberdayaan masyarakat dapat memiliki inisiatif dan kemampuan untuk mengelola sendiri sumber daya mereka. Sehingga dengan mereka dapat mengelola dan membentuk penggalian kemampuan pribadi, kreatifitas, kompetensi dan daya 
pikir dapat merubah kehidupannya pula dengan kemampuan dan keahlian yang dimiliki.

Di Kecamatan Langsa kota ada sepuluh desa yang terdiri dari desa Blang, desa Blang Seunibong, desa Jawa, desa Tualang Teungoh, Desa Muetia, Alue Beurawe, desa Teungoh, desa Daulat, desa Blang Paseh dan desa Peukan langsa. di desa ini sendiri juga memiliki anggaran Dana Desa yang berasal dari dana Anggaran Pendapatan Belanja Negara. Dana yang didapatkan ini kemudian dalam proses pengalokasiannya dibagi ke dalam 4 aspek yaitu pemberdayaan, pembinaan, infrastruktur dan dana yang tak terduga. Keempat aspek ini bertujuan untuk meningkatkan pemberdayaan masyarakat desa Alue sehingga Alue Beurawe dapat meningkatkan taraf perekonomian masyarakat. ${ }^{6}$

Pemanfaatan Dana Desa Kecamatan Langsa Kota digunakan untuk pembangunan jalan poros dusun, jalan poros desa, jalan lingkungan, jalan setapak, jalan akses lahan, Pintu Gerbang dusun dan lain-lain. Peningkatan pembangunan infrastruktur desa di Kecamatan Langsa Kota secara merata sesuai dengan kebutuhan desa melalui optimalisasi penggunaan Dana Desa, dengan melakukan perencanaan pembangunan dari desa, pelaksanaan, pengawasan dan pelaporan hasil pengunaan Dana Desa untuk pembangunan.

Ketimpangan dan kesenjangan ekonomi masyarakat desa dipengaruhi oleh ketidaktepatan atau pemanfaat dana desa sehingga berdampak terhadap masyarakat desa. Perangkat desa memiliki wewenang dalam mengolala dana desa untuk kepentingan masyarakat dalam kesejahteraan ekonomi.

Pelaksanaan bidang pemberdayaan kemasyarakatan desa di Desa Alue Beurawe, desa Muetia diantaranya pelatihan tim pengelola kegiatan, pembinaan fasilitas bantuan hukum kepada masyarakat, pengembangan kapasitas lembaga kemasyarakatan pengembangan sistem informasi desa, pengembangan potensi desa, pengembangan perencanaan partisipatif, pelatihan kewirausahaan. Pemanfaatan dana desa dalam peningkatan ekonomi masyarakat desa sangat ditentukan dari kebijakan yang diambil oleh perangkat desa. Keterlibatan masyarakat dalam setiap elemen memberikan dampak yang positif.

Pemberdayaan ekonomi ditingkat desa ada yang berdampak positif dan negatif.Keterlibatan masyarakat dalam keterlibatan sangat penting dalam pemberdayaan seperti pembekalan ekonomi kreatif yang dilakukan ditingkat desa 
untuk menunjang ekonomi di desa. Dampak negatif ada sebagian masyarakat tidak dilibatkan dalam kegiatan ini, hal ini dipengaruhi oleh komunikasi yang tidak baik.

Ada beberapa pelaksanaan pembangunan infrastruktur di Desa Langsa Kota terlaksana dengan baik, penggunaan dana desa diperuntukkan untuk pembangunan dan pemberdayaan masyarakat.Peran pemerintah dan dukungan masyarakat secara partisipatif menjadikan pembangunan tepat sasaran dan merata. Disisilain problem yang dihadapi di dalam masyarakat desa seperti tidak dimanfaatkan buruh harian setempat sehingga terjadi kesenjangan dalam masyarakat.Ini berdampak kepada masyarakat yang memiliki kemampuan dalam buruh kasar, sehingga menimbulkan dampak negatif secara sosial ekonomi.

Pembangunan yang mendukung prinsip pemerataan, akan menghasilkan pembangunan yang adil, makmur serta sejahtera bagi masyarakatnya. Pembangunan infrastruktur juga bermanfaat bagi pemberdayaan masyarakat. Islam memandang suatu keberdayaan atas masyarakat menjadi hal yang penting sehingga pemberdayaan dalam pandangan Islam telah memiliki paradigma yang holistik dan strategis. Pemberdayaan dalam konteks pengembangan masyarakatIslam merupakan sebuah pembelajaran kepada masyarakat agar dapat mandiri melakukan upaya perbaikan kualitas hidup yang menyangkut tentang kesejahteraan dan keselamatan dunia dan akhirat.

Selain untuk meningkatkan taraf perekonomian masyarakat, Pemerintah desa Alue Beurawe tentu juga harus memperhatikan sistem pengelolaan dana desa yang dijalankan sehingga tidak bertentangan dengan sistem perekonomian yang telah ditetapkan dalam Islam. ${ }^{7}$ Oleh karena itu di dalam penelitian ini penulis ingin mengetahui sejauh mana pegelolaan dana desa yang dilakukan oleh Pemerintah desa di kecamatan Langsa Kota, dan apakah pengelolaan dana yang dijalankan sudah sesuai dalam meningkatkan perekonomian masyarakat desa. Sehingga penulis melakukan penelitian yang terkait pengelolaan dana desa dalam meningkatkan perekonomian masyarakat di Kecamatan Langsa Kota, Kota Langsa.

\section{Tinjauan Tentang Pengelolaan}

Pengelolaan merupakan terjemahan dari kata "management", terbawa oleh derasnya arus penambahan kata pungut ke dalam bahasa Indonesia, isilah 
inggris tersebut lalu di Indonesia menjadi manajemen. Dalam kamus Bahasa Indonesia lengkap disebutkan bahwa pengelolaan adalah proses atau cara perbuatan mengelola atau proses melakukan kegiatan tertentu dengan menggerakkan tenaga orang lain, proses yang membantu merumuskan kebijaksanaan dan tujuan organisasi atau proses yang memberikan pengawasan pada semua hal yang terlibat dalam pelaksanaan kebijaksanaan dan pencapai tujuan. $^{8}$

Menurut Suharsimiarikunto pengelolaan adalah subtantifa dari mengelola, sedangkan mengelola berarti suatu tindakan yang dimulai dari penyusunan data, merencana, mengorganisasikan, melaksanakan, sampai dengan pengawasan dan penilaian. Dijelaskan kemudian pengelolaan menghasilkan suatu dan sesuatu itu dapa tmerupakan sumber penyempurnaan dan peningkatan pengelolaan selanjutnya. ${ }^{9}$

Marry Parker Follet mendefinisikan pengelolaan adalah seni atau proses dalam menyelesaikan sesuatu yang terkait dengan pecapaian tujuan. Dalam penyelesaian akan sesuatu tersebut, terdapat tiga faktor yang terlibat:

1. Adanya penggunaan sumber daya organisasi, baik sumber daya manusia maupun faktor-faktor produksi lainya.

2. Proses yang bertahap mulai dari perencanaan pengorganisasian, pengarahan dan pengimplementasian, hingga pengendalian dan pengawasan.

3. Adanya seni dalampenyelesaian pekerjaan. ${ }^{10}$

Menurut pengertian di atas dapat diuraikan yang pertama, manajemen sebagai suatu proses. Dalam buku encyclopedia of the social sciences dikatakan bahwa manajemen adalah suatu proses dengan proses di mana pelaksanaan suatu tujuan tertentu diselenggarakan dan diawasi. Sedangkan menurut pengertian yang kedua, manjemen adalah kolektivitas orang-orang yang melakukan aktivitas manajemen. Dan menerut pengertian yang ketiga, manajemen adalah suatu seni atau ilmu perencanaan, pengorganisasian, penyusunan, pengarahan, dan pengawasan daripada sumber daya manusia untuk mencapai tujuan yang sudah ditetapkan terlebih dahulu. ${ }^{11}$

Berdasarkan beberapa pendapat ahli di atas, penulis menyimpulkan bahwa pengelolaan merupakan suaturangkaian kegiatan yang meliputi merencanakan, 
mengorganisasikan dan mengarahkan, dan mengawasi kegiatan manusiadengan memanfaatkan material dan fasilitas yang ada untuk mencapai tujuan yang telah ditetapkan secara efektif dan efisien.

Jadi dapat disimpulkan bahwa pengelolaan (manajemen) adalah suatu cara atau proses yang dimulai dari perencanaan, pengorganisasian, pengawasan dan evaluasi untuk mencapai suatu tujuan yang telah ditentukan agar berjalan efektif dan efisien.

\section{Dana Desa}

Secara bahasa Dana Desa terdapat dua kata yaitu Dana dan Desa. Dana adalah uang yang disediakan untuk suatu keperluan. ${ }^{12}$ Sedangkan desa secara etimologi berasal dari kata swadesi (bahasa sansekerta) yang berarti wilayah, tempat atau bagian yang mandiri dan otonom. Desa dapat didefinisikan sebagai kesatuan masyarakat hukum yang memiliki batas-batas wilayah yang berwenang untuk mengatur dan mengurus kepentingan masyarakat setempat, berdasarkan asal usul, adat istiadat setempat yang diakui dan dihormati dalam sistem pemeritahan Negara Kesatuan Republik Indonesia (NKRI). ${ }^{13}$ Aceh memiliki keistimewaan dalam penyebutan Gampong, sesuai dengan Qanun No 5 Tahun 2003 penyebutan nama desa khusus untuk Aceh disebut Gampong. Gampong memiliki pengertian yang sama dengan desa.

Menurut UU No. 23 tahun 2014 pasal 294 ayat 3, Dana Desa dialokasikan oleh Pemerintah Pusat Untuk mendanai penyelenggaraan pemerintahan, pelaksanaan pembangunan, dan pembinaan kemasyarakatan, serta pemberdayaan masyarakat Desa sesuai dengan ketentuan undang-undang mengenai Desa. Dana Desa adalah dana yang bersumber dari APBN yang diperuntukkan bagi Desa dan ditransfer melalui APBD Kabupaten/Kota setiap tahun, untuk membiayai penyelenggaraan kewenangan Desa berdasarkan hak asal usul, dan kewenangan local skala Desa. ${ }^{14}$

Menurut Peraturan Menteri desa, pembangunan daerah tertinggal dan transmigrasi No. 21 tahun 2015, Dana Desa adalah dana yang bersumber dari Anggaran Pendapatan dan Belanja Negara yang diperuntukkan bagi Desa yang ditransfer melalui Anggaran Pendapatan dan Belanja Daerah kabupaten/kota dan digunakan untukmendanai penyelenggaraan pemerintahan,pelaksanaan pembangunan, pembinaan kemasyarakatan, dan pemberdayaan masyarakat. 
Dana Desa diprioritaskan untuk membiayai pelaksanaan program dan kegiatan berskala lokal Desa bidang Pembangunan Desa dan Pemberdayaan Masyarakat Desa.

\section{Pengembangan dan Pemberdayaan Masyarakat}

Pengembangan masyarakat adalah upaya mengembangkan sebuah kondisi masyarakat secara berkelanjutan dan aktif berlandaskan prinsip-prinsip keadilan sosial dan saling menghargai. Para pekerja kemasyarakatan berupaya memfasilitasi warga dalam proses terciptanya keadilan sosial dan saling menghargai melalui program-program pembangunan secara luas yang menghubungkan seluruh komponen masyarakat. Pengembangan masyarakat menterjemahka nnilai-nilai keterbukaan, persamaan, pertanggungjawaban, kesempatan, pilihan, partisipasi dan saling menguntungkan, saling timbale balik dan pembelajaran terus menerus. Inti dari pengembangan masyarakat adalah mendidik, membuat anggota masyarakat mampu mengerjakan sesuatu dengan memberikan kekuatan atau sarana yang diperlukan dan memberdayakan mereka. ${ }^{15}$ Pengembangan dan pemberdayaan masyarakat merupakan upaya yang dilakukan untuk melakukan perubahan masyarakat dalam meningkatan ekonomi menjadi lebih baik dari sebelumnya.

Pengembangan masyarakat didasari sebuah cita-cita bahwa masyarakat bisa dan harus mengambil tanggung jawab dalam merumuskan kebutuhan, mengusahakan kesejahteraan, menangani sumber daya baik sumber daya alam maupun sumber daya manusia dan mewujudkan tujuan hidup mereka sendiri. Pengembangan masyarakat diarahkan unuk membangun supportive communities, yaitu sebuah struktur masyarakat yang kehidupannya didasarkan pada pengembangan dan pembagian sumber daya secara adil serta adanya interaksi sosial, partisipasi, dan upaya saling mendorong antar satu dengan yang lain. ${ }^{16}$ Salah satu tujuan pengembangan masyarakat adalah membangun sebuah struktur masyarakat yang didalamnya memfasilitasi tumbuhnya partisipasi secara demokratis ketika terjadi pengambilan keputusan.

Sedangkan pemberdayaan berarti menyediakan sumber daya, kesempatan, pengetahuan dan keterampilan dalam rangka meningkatkan kemampuan warga miskin untuk menentukan masa depannya sendiri dan berpartisipasi dalam kehidupan masyarakatnya. ${ }^{17}$ Pemberdayaan masyarakat adalah proses 
pembangunan dimana masyarakat berinisiatif untuk memulai proses kegiatan sosial untuk memperbaiki situasi dan kondisi diri sendiri. ${ }^{18}$ Pemberdayaan hanya bisa terjadi apabila warganya ikut berpartisipasi.

Pemberdayaan adalah langkah atau proses mengupayakan unsur-unsur keberdayaan dalam masyarakat sehingga mereka mampu meningkatkan harkat dan martabat dan keluar dari sebuah ketergantungan yang mengkondisikan mereka dalam perangkap kemiskinan dan keterbelakangan, atau dengan istilah lain memandirikan masyarakat. ${ }^{19}$

Pada dasarnya dalam Islam para umatnya juga dianjurkan untuk senantiasa melakukan pemberdayaan dan pengembangan baik dalam aspek ekonomi, sosial, agama, ataupun sosial budaya. Disamping itu sebagai umat Islam juga dianjurkan untuk terus berusaha dan menggali potensi yang dimiliki oleh komunitas tersebut baik berupa sumberdaya manusia maupun sumberdaya alam, sebagaimana disinyalir dalam Alqur'an potongan Surat Ar-Ra'd ayat 11 sebagai berikut:

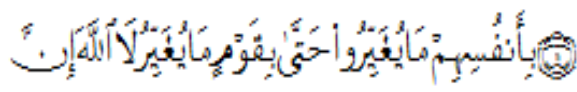

Artinya: Sesungguhnya Allah tidak merobah keadaan sesuatu kaum sehingga mereka merobah keadaan yang ada pada diri mereka sendiri. ${ }^{20}$

Dari ayat di atas, dapat dipahami bahwa sebagai makhluk sosial seharusnya senantiasa melakukan proses-proses pemberdayaan untuk meningkatkan kualitas hidup masyarakat. Hal paling penting yang harus dilakukan dalam pemberdayaan masyarakat adalah keterlibatan masyarakat itu sendiri, mulai dari penentuan masalah dan bagaimana mengatasi permasalahan yang dilakukan oleh masyarakat, begitu pula dengan melakukan aksi perubahan melalui berbagai program yang disusun oleh masyarakat, yang mampu menjawab kebutuhan masyarakat.

Menurut Suharto Pemberdayaan adalah sebuah proses dantujuan. Sebagai proses, pemberdayaan adalah serangkaian kegiatan untuk memperkuat kekuasaan atau keberdayaan kelompok lemah dalam masyarakat, termasuk individu-individu yang mengalami masalah kemiskinan. Sebagai tujuan, maka pemberdayaan menunjuk pada kedaan atau hasil yang ingin dicapai oleh sebuah perubahan sosail; yaitu mayarakat yang berdaya, memiliki kekuasaan atau mempunyai pengetahuan dan kemampuan dalam memenuhi kebutuhan hidupnya baik yang bersifat fisik, ekonomi, maupun sosial seperti memiliki kepercayaan diri, 
262 AT-TAWASSUTH: Jurnal Ekonomi Islam, Volume IV No. 2 Juli Desember 2019: 252 - 276

mampu mneyampaikan aspirasi, mempunyai mata pencaharian, berpartisipasi dalam kegiatan sosial, dan mandiri dalam melaksanakan tugas-tugas kehidupannya. $^{21}$

Menurut Jim Ife, konsep pemberdayaan memiliki hubungan erat duakonsep pokok yakni: konsep power (daya) dan konsep Disadvanteged (ketimpangan). Upaya pemberdayaan masyarakat perlu didasari pemahaman bahwa munculnya ketidak berdayaan masyarakat akibat masyarakat tidak memiliki kekuatan (powerless). Jim Ife mengidentifikasi beberapa jenis kekuatan yang dimiliki masyarakat yang dapat digunakan untuk memberdayakan mereka: ${ }^{22}$

a. Kekuatan atas pilihan pribadi. Upaya pemberdayaan dilakukan dengan memberikan kesempatan kepada masyarakat untuk menentukan pilihan pribadi atau kesempatan untuk lebih baik.

b. Kekuatan dalam menentukan kebutuhannya sendiri dengan mendampingi mereka untuk merumuskan kebutuhannya sendiri.

c. Kekuatan dalam kebebasan berekspresi dengan mengembangkan kapasitas mereka untuk bebas berekspresi dalam bentuk budaya politik.

d. Kekuatan kelembagaan dengan meningkatkan aksebilitas terhadap kelembagaan pendidikan, kesehatan, keluarga, keagamaan, sistem kesejahteraan sosial, struktur pemerintah, media dan sebagainya.

e. Kekuatan sumber daya ekonomi dengan meningkatkan aksebilitas dan kontrol terhadap aktivitas ekonomi.

f. Kekuatan dalam kebebasan reproduksi dengan memberikan kebebasan kepada masyarakat dalam menentukan proses reproduksi.

Konsep pemberdayaan masyarakat jika ditelaah sebenarnya berangkat dari pandangan yang menempatkan manusia sebagai subjek dari dunianya sendiri. Pola dasar gerakan pemberdayaan ini mengamanatkan kepada perlunya power dan menekankan keberpihakan kepada kelompok yang tak berdaya. Pemberdayaan bersifat holistik berarti ia mencakup semua aspek. Untuk itu setiap sumber daya lokal patut diketahui dan didayagunakan.Hal ini untuk menghindarkan masyarakat dari sikap ketergantungan kepada segala sesatu. ${ }^{23}$

Pemberdayaan sangat penting kesadaran masyarakat untuk kepentingan bersama. Ini akan berdampak untuk desa dalam kemandirian menuju masyarakat kesejahteraan ekonomi dalam pembangunan di desa. Pemangku memiliki 
kewajiban membantu masyarakat meningkatkan dan kemandirian dalam ekonomi masyarakat.

\section{Metodologi Penelitian}

Penelitian ini menggunakan metode kualitatif dengan studi fenomenologi. Yaitu peneliti yang terlibat langsung dalam situasi dan latar belakang fenomena yang diteliti serta memusatkan perhatian pada suatu peristiwa kehidupan sesuai dengan konteks penelitian. Dimana akan membantu peneliti memasuki sudut pandang orang lain,dan berupaya memahami mengapa mereka menjalani hidupnya dengan cara seperti itu. Fenomenologi bukan hanya memungkinkan peneliti untuk melihatdari perspektif partisipan metode ini juga menawarkan semacam cara untuk memahami kerangka yang telah dikembangkan oleh tiap-tiap individu, dari waktu ke waktu, hingga membentuk tanggapan mereka terhadap peristiwa dan pengalaman dalam kehidupannya. Penelitian ini akan dilaksanakan di Kecamatan Langsa Kota, Kota Langsa.

Sumber data primer diperoleh langsung dari desa di kecamatan Langsa kota, Kantor Geuchik dan masyarakat yang ada di kecamatan Langsa Kota. Sedangkan sekunderadalahdata yang diperoleh dari dokumen resmi, buku-buku, majalah dan berbagai literature yang relevan dengan pembahasan penelitian ini. Jadi pengumpulan data sekunder ini melalui orang kedua baik berupa informan atau buku literatur, yaitu buku-buku, artikel, surat kabar dan lain-lain yang berkaitan dengan pembahasan. ${ }^{24}$ Data sekunder ini membantu peneliti untuk mendapatkan bukti maupun bahan yang akan diteliti, sehingga peneliti dapat memecahkan atau menyelesaikan suatu penelitian dengan baik karena didukung dari buku-buku, baik yang sudah dipublikasikan maupun yang belum dipublikasikan.

Teknik pengumpulan data yang digunakan dalam penelitian ini sesuai dengan jenis penelitian kualitatif deskriptif, yaitu peneliti merupakan istrumen utama (key Intrument), yang secara langsung terlibat dalam proses pengumpulan data melalui observasi, wawancara dan dokumentasi (cacatan atau arsip).

\section{Hasil Penelitian dan Pembahasan}

Proses penyusunan rencana pembangunan desa dengan melibatkan masyarakat dalam bentuk musyawarah tersebut juga dilakukan di Desa Alue Beurawe. Hal ini disampaikan oleh Bapak Mahdinur selaku masyarakat Desa Alue Beurawe, melalui kutipan berikut ini. 
"Pada proses perencanaan penggunaan dana desa kami dilibatkan melalui musyawarah dusun dan musyawarah desa untuk pengalokasian perencanaan pembangunan desa.Dengan adanya musyawarah diharapkan akan mampu memfasilitasi kebutuhan kami, terutama kebutuhan yang paling mendesakbagi masyarakat". ${ }^{25}$

Hal demikian tidak hanya berlaku dalam Desa Alue Beurawe. Bapak Adnan sebagai masyarakat Desa Meutia menyampaikan proses serupa melalui kutipan berikut ini.

“...kami sebagai warga akan selalu memberikan masukan berupa usulan untuk pelaksanaan perencanaan pembangunan desa. dan tentu akan dipilih kembali kegiatanmanayangakandisetujuioleh aparatur desa. Kami berharap dengan sumbangsih usulan dari warga akan mampu meningkatkan kesejahteraan kami”. ${ }^{26}$

Proses perencanaan dana desa sudah menggunakan aspirasi masyarakat ditunjukkandengan keterlibatanmasyarakatdalam proses musyawarah dusun dan musyawarah desa, yang ditunjukkan oleh Desa Alue Beurawe dan desa Meutia. Masyarakat desa berpartisipasi dalam proses identifikasi permasalahan yang ada termasuk alternatif solusinya, potensi yang dimiliki desa, serta pelibatan mereka untuk evaluasi ketika terjadi perubahan. Hal ini sesuai perencanaan program Dana Desa di Desa Alue Beurawe dan desa Meutia secara bertahap telah melaksanakan konsep pembangunan partisipatif masyarakat desa yang dibuktikan dengan penerapan prinsip partisipatif, responsif, transparansi dalam rangka mewujudkan pemberdayaan masyarakat desa melalui forum Musrenbangdes (Musyawarah Perencanaan Pembangunan Desa).

Terkait dengan kemampuan pemerintah desa dalam pengelolaan alokasi dana desa di Desa Alue Beurawe dan Desa Meutia yang memiliki beberapa faktor yang dapat mempengaruhi terhambatnya terlaksananya dana desa di desa Alue Beurawe dan Meutia. Hal ini di sampaikan oleh Kepala Desa, Burhanuddin:

"Terhambatnya pelaksanaan alokasi dana desa itu diakibatkan karena kurangnya sumber daya manusia." 27

Pernyataanyang sama juga disampaikan oleh Ketua BP Desa Alue Beurawe, Abdullah Arya: 
"Masalah kemampuan aparat desa, selaku pelaksana dana desa itu sangat memiliki tanggung jawab yang besar terhadap tugas yang diberikan. Saya perhatikan semua aparat desa yang menjadi aktor dalam pengelolaan alokasi dana desa itu semangat dalam bekerja. Namun ada kelemahan sebagian aparat desa dalam mengelola dana desa sehingga terjadinya silpa" 28

Pernyataan-pernyataan yang disampaikan oleh Kepala Desa Burhanuddin;

"Kalau tentang kekuatan aparat desa dalam pelaksanaan alokasi dana desa di desa ini, saya sudah melihat kinerja mereka beberapa tahun kemarin bahwa dimana mereka apabila diberikan tugas maka mereka akan Mengerjakan dana menyelesaikan pekerjaan itu dengan baik, contohnya dalam pengelolaan alokasi dana desa ini. ${ }^{29}$

"Kalau masalah kelemahan mungkin kelemahan aparat desa itu dalam pelaksanaan alokasi dana desa yaitu terlambatnya pembuatan laporan atau LPJ dana desa yang akan diserahkan kepada pertama, yaitu BP Desa kemudian diserahkan ke Camat Langsa Kota, yang seharusnya akhir tahun harus diselesaikan dan ternyata awal bulan baru disetor. Itu salah satu kelemahan aparat desa". ${ }^{30}$

Selain itu, pengelolaan keuangan desa di dalamnya harus terdapat prioritas penggunaan.Hal ini diungkapkan oleh Burhanuddin kepala desa Alue Beurawe melalui kutipan berikut ini."Dana desa kami prioritas untuk pembangunan jalan dan rehab rumah kaum duafa dan fakir miskin".

Hal serupa juga terjadi pada desa alue Beurawe.Penyusunan anggaran tetap memerhatikanprioritaspenggunaan walaupun berbeda dengan desa lainnya.Bapak sulaiman Ishak menjelaskannya melalui kutipan berikut ini.

"Dana Desa Alue Beurawe kami prioritaskan untuk membangun dan merawat saluran irigasi, membangun jalan. Selain itu tahun 2018, kami melakukan bantuan jaring ikan dan jala". ${ }^{31}$

Proses penggunaan Dana Desa akan melalui proses perencanaan penggunaannya. Masing-masing desa akan memiliki kebijakan yang berbedabeda, tapi yang umum ditunjukkan dengan dilakukan musyawarah dusun atau musyawarah desa. Proses dimulai dari adanya usulan kegiatan dari tingkat lorong 
ke kepala desa yang kemudian ke dusun berdasarkan usulan dari masyarakat. Ini juga didukung dari pernyataan Bapak Mahdinur, selaku masyarakat Desa Alue Beurawe, melalui kutipan berikut ini.

"Di desa kami menggunakan swadaya masyarakat yang secara gotong royong dalam membangun desa. Dengan pelaksanaan gotong royong akan mempererat silaturahmi yang antar masyarakat, dan akan memampu membawa kami ke dalam rasa saling memiliki dan menjaga desa untuk kenyamanan. Pada saat kami memiliki rasa saling memiliki kami akan saling mengawasi dan mengingatkan jika salahsatu dari kami keluar dari perilaku yang melanggar dari norma-norma yang berlaku dalam masyarakat". 32

Apabila pembangunan telah dilaksanakan, maka tim pelaksana kegiatan wajib menyampaikan laporan yang menjelaskanprogresspelaksanaan kegiatan kepada kepala desa. Dalam pelaporan tersebut juga terdapat informasi tentang penggunaan dana desa sesuai yang diterima tim. Apabila proses pembangunan desa telah selesai, kepala desa akan melaporkan pelaksanaan pembangunan tersebut. Laporan ini akan disampaikandalam musyawarah desayang diselenggarakan oleh Badan Permusyawaratan Desa (BPD).

Penggunaan dana desa di Alue Beurawe untuk kegiatan pembangunan, yang diprioritaskan pada pembangunan atau perbaikan saluran irigasi, pengaspalan jalan desa untuk pembangunan infrastruktur lainnya. Pengelolaan penggunaan dana desa untuk kegiatan-kegiatan tersebut tentunya diawali dengan pembentukan tim pelaksana kegiatan oleh kepala desa.

Dengan perencanaan dengan model partisipatif dilakukan melalui musrenbang desa dengan melibatkan seluruh elemen masyarakat mulai dari lembaga masyarakat, tokoh masyarakat dan seluruh masyarakat desa. Musrenbang desa tersebut bertujuan untuk mendorong masyarakat agarturut serta berpartisipasi dalam menyusun dan menentukan rencana kegiatan pembangunan di desa. Sehingga rencana kegiatan yang tertuang dalam Daftar Usulan Rencana Kegiatan (DURK) yang dihasilkan adalah gambaran dari harapan dan kebutuhan seluruh masyarakat setempat. ${ }^{33}$

Akan tetapi, hasil pengamatan dan informasi yang diperoleh menunjukan bahwa kegiatan musrembang dalam tahapan perencanaan di Gampong Geudubang 
Jawa masih sebatas kepada memenuhi ketentuan dan belum menyentuh kepada esensi yang terkandung dari maksud kegiatan musrenbang desa.

Informasi ini seperti pernyataan salah satu anggota masyarakat, yaitu bapak Adnan yang mengatakan bahwa:

"Kami masyarakat desa ini masih kurang paham dengan apa itu perencanaan untuk membangun desa, di tambah lagi pemerintah desa juga tidak pernah menjelaskan kepada kami. Jadi wajar kalau saya pribadi dan sejumlah masyrakat lainnya hanya datang untuk sekedar hadir, karena memang kami tidak tahu harus bicara apa". ${ }^{34}$

Dari hasil wawancara peneliti dengan beberapa informan pada tahap perencanaan yaitu BapakAdnan, menemukan bahwa kurangnya kepedulian masyarakat dan kurangnya transparansi dari pihak pemerintah desa dalam Pengelolaan Alokasi Dana Desa, serta kurangnya pemahaman masyarakat mengenai tahapan perencanaan pembangunan dalam PengeloaanAlokasi Dana Desa dalam meningkatkan pembangunan fisik dan non fisik desa Meutia.

\section{Pemberdayaan Masyarakat Sebelum dan Sesudah Adanya Dana Desa}

Prioritas penggunaan Dana Desa untuk pengembangan potensi ekonomi lokal didasarkan atas kondisi dan potensi desa, sejalan dengan pencapaian target RPJM Desa dan RKP Desa setiap tahunnya. ${ }^{35}$

Dalam wawancara dengan Bapak Sulaiman Ishak selaku Kasi Pemerintahan desa Alue Beurawe, dimana pemberdayaan yang telah dilakukan pemerintah desa terhalang dengan kurangnya dana dan sebelum adanya dana desa pemerintahan desa hanya melakukan pemberdayaan yang minim dengan dana seadanya.

"Keadaan ekonomi masyarakat Desa Meutia secaraumum sebenarnya tidak terlalu buruk, baik itu sebelum ada dana desa ini. Masyarakat ada yang bertani, dan juga sebagai buruh tani, berdagang, PNS dan yang lainnya. Dana desa ini dipriorotaskan untuk pembangunan infrastruktur untuk pada tahun ini. Maka keadaan infrastruktur sebelum adanya dana desa cukup berbeda dengan setelah adanya dana desa. Sebelum adanya dana desa, keadaan infrastruktur belum mendapatkan perbaikan, seperti jalan dan jembatan belum ada perbaikan. Keadaan infrastruktur sebelum adanya dana desa kondisinya kurang layak, seperti jalan di kampung-kampung yang rusak, jembatan juga sama. 
Selain itu juga, ketika kami pihak pemerintah desa mau mengadakan perbaikan infrastruktur misalkan, kami selalu berbenturan dengan dana yang tersedia, cukup sulit kalau sebelum adanya dana desa."

Dari hasil wawancara yang telah dilakukan, dapat disimpulkan bahwa Pemberdayaan masyarakat sebelum adanya dana desa sangat terbatas dalam segi pendanaan dan program yang akan dilaksanakan oleh pemerintah desa. Pemberdayaan masyaraka tdan pembangunan infrastruktur Desa Alue Beurawe di kala itu bersifat swadaya gotong royong masyarakat dengan sukarela.

Dampak adanya peran dana desa dirasa sangat membantu dalam pemberdayaan dan pembangunan infrastruktur di desa Alue Beurawe, dengan adanya dana desa pemerintah dapat menjalankan program-program yang telah disepakati bersama antara pemerintah desa, masyarakat dan lembaga-lembaga yang ada di Desa Alue Beurawe. Pemberdayaan masyarakat setelah adanya dana desa pembangunan dan pemberdayaan mulai berjalan dengan lancar, dalam artiannya pembangunan terus meningkat dan berjalan membenahi infrastruktur desa seperti jalan dan parit yang setelah adanya dana desa dapat diperbaiki. Beberapa jalan desa yang tadinya keterbatasan sekarang meningkat menjadi jalan dan parit cor beton.

Dalam Undang-Undang Nomor 6 Tahun 2014 telah dijelaskan bahwa desa bukanlah hanya menjadi objek penerima manfaat akan tetapi desa dapat menjadi subjek pemberi manfaat kepada warga masyarakat desa. Dengan demikian pemerintah desa harus melibatkan seluruh lapisan masyarakat dalam pemanfaatan dana desa yang ditujukan untuk pembangunan dan pemberdayaan masyarakat.

Dalam wawancara dengan Bapak Amarullah selaku kasi Pemerintahan desa Meutia dikatakan bahwa:

"Dampak adanya dana desa, pemerintah desa mengajak dan merangkul seluruh lapisan masyarakat dalam pemberdayaan dan pembangunan agar bisa ditingkatkan dari berbagai elemen, baik itu pemberdayan kependudukannya, kesejahteraanya, perempuannya, dan sebagainya, sedikit-sedikit kita tingkatkan demi perbaikan berbagai sektor. Contohnya adalah dalam kegiatan kesehatan, yaitu pengkaderan posyandu dan dalam bidang pendidikan, yaitu pengadaan sarana dan prasarana pendidikan di 
bawah umur (PAUD) pemberdayaan LINMAS". ${ }^{36}$

Dari hasil wawancara dengan kasi pemerintahan desaAlue Beurawe dan desa Meutia dapat disimpulkan bahwa setelah adanya dana desa pembangunan serta pemberdayaan masyarakat dapat meningkat.

\section{Bentuk Pemberdayaan Masyarakat Di Desa Langsa Kota}

Dalam upaya untuk menjadikan desa yang maju, Pemerintah desa Alue Beurawe dan desa Meutia terus berusaha untuk meningkatkan pembangunan serta pemberdayaan masyarakat dalam berbagai aspek. Beberapa usaha tersebut telah berhasil direalisasikan dengan baik, namun masih banyak juga hal-hal yang harus ditingkatkan dan diwujudkan agar masyarakat serta desa sendiri menjadi semakin berkembang.

Bapak Amarullah selaku Kaur Pemerintahan desa Meutia dengan menanyakan apa saja bentuk-bentuk pemberdayaan masyarakat yang selama ini telah terwujud. Beliau menjawab:

"Jika ditanyakan apa saja bentuk-bentuknya tentu telah banyak yang terwujud. Namun saya dapat mengatakan bahwa perealisasian dengan adanya dana desa didasari dari beberapa aspek, yaitu infrastruktur, dan pemberdayaan masyarakat di bidang umum dan juga keagamaan". ${ }^{37}$

Kemudian beliau juga menjelaskan bahwa beberapa infrastuktur yang telah terealisasi yang bersumber dari dana desa adalah pembuatan parit, jalan. Selain itu juga dana desa ini digunakan untuk pemasangan paving blok, perbaikan mesjid di desa Meutia, dan pembelian tenda dan kursi yang digunakan untuk kepentingan bersama masyarakat desa. ${ }^{38}$

Dalam pembangunan infrastruktur ini pula pemerintah desa Meutia mengupayakan pemberdayaan masyarakat didalamnya, yaitu dengan cara menjadikan masyarakat desa Meutia sendiri yang bekerja dalam pembangunan desa, yaitu dilibatkan dalam sektor fisik. Hal ini dimaksudkan agar masyarakat desa Meutia lebih produktif, selain itu juga untuk menumbuhkan rasa kerjasama antar masyarakat. Namun walaupun pembangunan ini dilakukan untuk kepentingan bersama dan dikerjakan oleh masyarakat desa Meutia sendiri, tapi masyarakat desa Meutia yang bekerja tetap diberikan gaji yang sesuai.

Selain dalam bidang infrastruktur, dari dana desa ini juga digunakan untuk pemberdayaan masyarakat dalam bidang umum dan keagamaan. Dalam 
270 AT-TAWASSUTH: Jurnal Ekonomi Islam, Volume IV No. 2 Juli -

Desember 2019: 252 - 276

bidang umum diwujudkan dengan adanya PKK, yang mana para ibu-ibu yang tergabung dalam PKK secara rutin melakukan kegiatan-kegiatan yang dapat meningkatkan pemberdayaan masyarakat, terutama untuk para ibu rumah tangga.

Kegiatan ibu-ibu PKK pemerintah desa Alue Beurawe sangat mendukung dalam pemberdayaan ekonomi, kegiatan seperti ini semua desa di Langsa kota memiliki tangung jawab sama-masa dalam meningkatkan perekonomian masyarakat, khususnya untuk ibu-ibu rumah tangga. Sebab dengan keberadaan ibu-ibu mendukung atau membantu suami dalam membiayai rumah tangga.Seperti Alue Beurawe salah satu program kami adalah melatih ibu-ibu penbuatan kue dan jait bordir dan ini di pasarkan ke Pasar, warung-warung dan kios-kios. $^{39}$

Bentuk pemberdayaan seperti ini efektif dalam pengembangan ekonomi masyarakat.Keterlibatan ibu-ibu rumah tangga dalam pengembangan ekonomi meringankan beban suami sebagai kepala rumah tangga untuk membiayai kebutuhan rumah tangga.

\section{Problem-problem Yang Dihadapi Pemerintah Desa Dalam Pengelolaan Dana Desa}

Dari hasil wawancara penulis dengan bapak Burhanuddin mengemukakan bahwa:

"Kami kesulitaan saat menyusun surat pertanggungjawaban untuk pencairan selanjutnya, karena sebagiandari aparat kami sebagian besar tidak memahami petunjuk penyusunan laporan sehingga lambat dalam menyelesaikan surat pertanggung jawaban tersebut". ${ }^{40}$

Maka salah satu hambatan yang dihadapi oleh pemerintah desa Alue Berawe adalah minimnya kualitas sumber daya manusia aparat desa.

1. Koordinasiyangkurang baik

Berikut ini hasil wawancara penulis dengan informan inti yang menanyakan masalah-masalah yang dihadapi dalam mengalokasikan dana tersebut. Berdasarkan hasil wawancara yang dilakukan terhadap Geuchik desa Meutia mengemukakan bahwa:

"Hambatan yang dihadapi oleh pemerintahdesa Meutia yaitu kurangnya koordinasi dari pihak- pihak yang terkait". ${ }^{41}$ 
Berdasarkan hasil wawancara penulis dengan Geuchik desa Alue Beurawe tersebut maka diketahui bahwa adanya koordinasi yang kurang baik terhadap instansi terkait sehingga menghambatproses pelaksanaan program tersebut dalam pengelolaan dana desa sehingga menyulitkan perangkat desa.

Sedangkan bapak Amarullah selaku Kaur Pemerintahan Gampon desa Meutia untuk menanyakan apa saja kendala yang dihadapi pemerintah desa dalam pengelolaan dana desa. Beliau menjawab:

"Kendala yang paling utama dalam pengelolaan dana desa ini adalah dananya yang sering terlambat cair. Padahal dana merupakan faktor utama dan paling penting untuk meningkatkan efektifitas". ${ }^{42}$

Beliau juga menambahkan bahwa dana desa ini akan cair setelah pembangunan di mulai. Menurut beliau hal ini membuat sulitnya melakukan pembangunan secara maksimal karena kurangnya dana yang ada. Selain itu, waktu keterlambatan dananya juga bukan sebentar, malah mencapai 3 sampai 4 bulan sehingga berdampak pada pembangunan yang dapat saja tertunda atau terbengkalai. ${ }^{43}$

Selainitu penulis juga mewawancarai Bapak Amarullah untuk menanyakan hal yang sama. Beliau menjelaskan:

"Hambatan dalam penyusunan dan penanggung jawaban laporan akhir tahun itu adalah karena harus menunggu petunjuk pembuatannya. Petunjuk ini misalnya berapa harga semen dan sebagainya untuk dibuat sehingga karena petunjuknya terlambat maka penyusunannya pun terlambat dan juga pengesahannya pun ikut terlambat." ${ }^{44}$

Geuchik desa Meutia M. Yusuf Hamid mengatakan:

"Kalau kita ada hambatan dalam penyusunan dan pembuatan pertanggung jawaban akhir tahun,karena kitaada acuannya. Tapi paling terhambatitudari sebagian perangkat desa tidak mampu membuat laporan sesuai dengam jadwal yang telah disepakati bersama di tingkat desa. Jika ini laporan ini tidak selesai akan berdampak untuk pembangunan kedepan. Ditingkat desa saja kami setiap tahun lembur membuat laporan ini untuk menyelesaikan laporan penggunaan dana desa." 45

Beliau juga menegaskan bahwa bukan berarti pengalokasian dana desa tahun-tahun yang lalu tidak benar, namun untuk memenuhi tujuan agar dana desa ini semakin lama menjadi semakin baik pengalokasiannya maka setiap tahunnya 
272 AT-TAWASSUTH: Jurnal Ekonomi Islam, Volume IV No. 2 Juli -

Desember 2019: 252 - 276

dilakukan perbaikan yang disesuaikan dengan keadaan dan lingkungan desasaat itu. ${ }^{46}$

\section{Pelaporan dan Tanggung Jawaban Dana Desa di Langsa Kota}

Pelaporan dan tanggung jawab terkait pengololaan keuangan desa. Pelaporan terkait pelaporan terkait dengan keuangan desa dilakukan secara bertahap yakni tahap pertama bulan Januari-Juni, tahap kedua bulan JuliSeptember dan tahap ketiga bulan Oktober-Desember. Untuk tahap pertama sudah selesai, sedangkan memasuki tahap kedua. Pada kenyataannya, laporan pertanggungjawaban ini sering terlambat, keterlambatan ini dipicu oleh pemerintah desa dalam tahap pembelajaran, dan ini menyebabkan pencairan dana menjadi terlambat.

Hal ini dibenarkan oleh kaur pemerintahan desa meutia:

"Untuk pelaporannya sendiri, bisa dikatakan tidak tepat waktu. Hal ini disebabkan, bendahara desa sebagai pengelola Sistem Keuangan Desa Meutia masih dalam pembelajaran dan proses adaptasi. Dan ini juga menyebebkan dana desa juga terlambat cair karena dana akan cair kalau sudah ada pelaporan tahap sebelumnya". ${ }^{47}$

Berdasarkan hasil wawancara di atas maka dapat disimpulkan bahwa pelaporan pertanggungjawaban yang dilakukan oleh desa itu tidak tepat waktu, hal ini disebabkan karena aparat pemerintah desa yakni bendahara desa belum terlalu fasih dalam megelola sistem keuangan desa. Dan hal ini juga menyebabkan pencairan dananya tidak bejalan dengan lancar atau sedikit tersendat.

Namun, laporan realisasi penggunaan dana desa yang dibuat oleh pemerintah desa yang berisikan program yang dilakukan oleh pemerintah desa yang didanai dari anggaran dana desa, setelah dibuat maka akan diadakan musyawarah desa yang dihadiri oleh aparat pemerintah desa, anggota Badan Permusyawaratan Desa dan tokoh masyarakat. Setelah dimusyawarahkan maka laporan realisasi ini kemudian dikirim ke kabupaten untuk diperiksa.

"Kalau mengenai pengawasan dana desa yang selama ini, kita di BPD itu dalam hal realisasi atau pelaksanaan program kita tidak terlalu jauh mencampuri urusan kepala desa tapi yang kita tuntut adalah bagaimana laporan realisisasi dari penggunaan dana desa. Karena laporan realisasi 
penggunaan dana desa harus dirapatkan dengan perangkat desa dan masyarakat." 48

Dalam tahap ini pemerintah Desa Alue Beurawe telah melakukannya sesuai dengan prosedur yang ditetapkan oleh pemerintah. Sehingga partisipasi dan pengawasan yang dilakukan oleh badan permusyawaratan desa dan masyarakat telah terlaksana dengan baik, hal ini bisa dilihat dengan dilakukannya rapat yang membahas laporan pertanggungjawaban kepala desa yang mengikutsertakan masyarakat dan anggota badan permusyawaratan desa.

Pertanggungjawaban merupakan tahapan terakhir pada proses Pengelolaan Alokasi Dana Desa yang dilakukan di Desa Alue Beurawe, pertanggungjawaban ini merupakan bentuk konsekuensi atas penggunaan dana yang telah dipercayakan oleh Pemerintah Desa.

\section{Kesimpulan}

Dari analisis dan pembahasan sebelumnya dapat ditarik kesimpulan bahwa Pengelolaan Dana desa selama ini telah berjalan dengan efektif, walaupun pengalokasiannya belum $100 \%$ efektif. Pengelolaan dana desa dikatakan telah berjalan efektif karena dapat ditinjau dari lapangan yang mempunyai bukti nyata, yaitu berupa pembangunan infrastruktur, pemberdayaan di bidang umum dan keagamaan. Ditinjau dari ekonomi maka pengelolaan dana desa belum sepenuhnya berjalan dengan baik. Upaya pemerintah dalam meningkatkan ekonomi masyarakat yaitu dengan melakukan pemberdayaan antara lain di bidang infrastruktur, pemberdayaan, bidang umum dan keagamaan. Pemberdayaan pada bidang infrastruktur adalah dengan adanya pembuatan parit, jalan, pembuatan jaring ikan atau jala dan pembuatan kue serta bordir. Dalam bidang umum diwujudkan dengan adanya PKK.

\section{Catatan}

${ }^{1}$ Azwardi, Sukanto, Efektifitas Alokasi Dana Desa (Add) Dan Kemiskinan Di Provinsi Sumatera Selatan, Jurnal Ekonomi Pembangunan, Volume 12, No. 1 (Juni2014), h 3.

${ }^{2}$ Chabib Sholeh dan Heru Rochansjah, Pengelolaan Keuangan Desa, (Bandung: FOKUS MEDIA, 2015), h.54

${ }^{3}$ Chandra Kusuma Putra, Ratih Nur Pratiwi, Suwondo, Pengelolaan Alokasi Dana Desa dalam Pemberdayaan Masyarakat Desa, (Malang, Jurnal Administrasi Publik, 2014), h.2

${ }^{4}$ Mudrajad Kuncoro, Dasar-dasar Ekonomi Pembangunan, (Yogyakarta:UPPSTIM YKPN, 2010), h.110 
${ }^{5}$ Departemen Agama RI Al-Qur'an dan terjemahnya Q.S: Ar-Ra'd (13) ayat 11, PT (Syaamil Cipta Media: Bandung,2005),h.368

${ }^{6}$ Burhanuddin Kepala Desa/ GeuchikDesa Alue Beurawe Tahun 2019,Langsa, 10 Januari 2019.

${ }^{7}$ Ibid.,

${ }^{8}$ Daryanto, kamus indonesia lengkap, (Surabaya: Apollo,1997), h. 348

${ }^{9}$ Suharsimi Arikunta, Pengelolaan Kelas Dan Siswa, (Jakarta:CV.Rajawali,1988), h. 8

${ }^{10}$ Erni Tisnawati Sule, Kurniwan Saefullah,Pengantarmanajemen, (Jakarta: Kencana PerdanaMedia Goup, 2009), h. 6

${ }^{11}$ M. Manulang, dasar-dasar Manajemen,(Jakarta: Ghalia Indonesi, 1990), h.15-17

${ }^{12}$ Kamus Besar Bahasa Indonesia, Pusat Bahasa Departemen Pendidikan Nasional, (Jakarta, PusatBahasa, 2008),h.314

${ }^{13}$ Syafrudin, Ateng dan Na'a, Suprin. Pergulatan Hukum Tradisional dan Hukum Moderen Dalam Desain Otonomi Desa.(P.T. Alumni, Bandung;2010), h.3

${ }^{14}$ Sutoro, et. Al. Dana Desa Untuk Membangun Indonesia (Tanya Jawab Seputar Dana Desa). Kementrian Desa, Pembangunan Daerah Tertinggal, dan Transmigrasi. Jakarta, 2016, h. 7

${ }^{15}$ Zubaedi, Pengembangan Masyarakat: Wacana dan Praktik,(Jakarta:Kencana,2014),h.4

${ }^{16}$ Ibid.,h.2

${ }^{17}$ Nanih Machendrawati, Agus Ahmad Safei, Pengembangan Masyarakat Islam dari Ideologi, Strategi, sampaiTradisi, (Bandung: PT. Remaja Rosdakarya, 2001), h.43

${ }^{18}$ JamesA. Cristenson, JerryW. Robinson, Community development in perspective, (Jr Ames:Ioa State Univercity Press, 1989)

${ }^{19}$ Anwar, Manajemen Pemberdayaan Perempuan (Bandung:Alfabeta, 2007), h. 1

${ }^{20}$ Departemen Agama RI Al-Qur'an dan terjemahnya Q.S: Ar-Ra'd (13) ayat 11, PT Syaamil Cipta Media, Bandung, 2005, h.368.

${ }^{21}$ Suharto,Edi. Membangun Masyarakat Memberdayakan Masyarakat. Cetakan III. (Bandung:PT RefikaAditama, 2009), h. 59-60

${ }^{22}$ Ife, J.W, Community Development: Creating Community Alternatives-vision, Analisys and Practice,(Melbourne: Longman, 2000), h.27

${ }^{23}$ Soetomo, Strategi-strategi Pembangunan Masyarakat, (Yogyakarta: Penerbit Pustaka Pelajar, 2006)Ibid.,h. 76-77

${ }^{24}$ Soerjono Soekanto, Pengantar Penelitian Hukum (Jakarta: RinekaCipta, 1986), h.12.

${ }^{25}$ Mahdinur. Masyarakat Desa Alue Beurawe Tahun 2019, Langsa, 20 Februari 2019

${ }^{26}$ Adnan masyarakat Desa MeutiaTahun 2019, Langsa, 28 Februari 2019

${ }^{27}$ Burhanuddin kepala Desa/ Geuchik DesaAlue Beurawe Tahun 2019, Langsa, 14 Februari 2019

${ }^{28}$ Abdullah Arya ketua BPdesa DesaAlue Beurawe Tahun 2019, Langsa, 14 Februari 2019

${ }^{29}$ Burhanuddin kepala Desa/ Geuchik DesaAlue Beurawe Tahun 2019, Langsa, 14 Februari 2019

${ }^{30}$ Ibid.,

${ }^{31}$ Sulaiman Ishak, Kasi Pemerintahan Desa Alue Beurawe Tahun 2019, Langsa, 20 Februari 2019

${ }^{32}$ Mahdinur masyarakat Desa Alue Beurawe Tahun 2019, Langsa, 20 Februari 2019

${ }^{33}$ Puti Andiny, JURNAL PENELITIANEKONOMI AKUNTANSI(JENSI): Analisis Alokasi Dana Desa Terhadap Pembangunan Wilayah di Desa GeudubangJawaKecamatan Langsa Baro, VOL. 2, NO.1, JUNI2018, h. 6

${ }^{34}$ Adnan masyarakat Desa MeutiaTahun 2019, Langsa, 28 Februari 2019

${ }^{35}$ Pasal 9 Peraturan Menteri Desa, Pembangunan Daerah Tertinggal dan Transmigrasi

Nomor 5 Tahun 2015 tentang Penetapan Prioritas Penggunaan Dana DesaTahun2015.

${ }^{36}$ Sulaiman Ishak, Kasi Pemerintahan Desa Alue Beurawe Tahun 2019, Langsa, 20 Februari 2019

${ }^{37}$ Amarullah, Kaur Pemerintahan desa Meutia Tahun 2019, Langsa, 20 April 2019

${ }^{38}$ Ibid.,

${ }^{39}$ Burhanuddin kepala Desa/ Geuchik Desa Alue Beurawe Tahun 2019, Langsa, 14 Februari 2019

${ }^{40}$ Ibid.

${ }^{41}$ Ibid.,

${ }^{42}$ Amarullah, Kaur Pemerintahan desa Meutia Tahun 2019, Langsa, 20 April 2019

${ }^{43}$ Ibid., 
${ }^{44}$ Ibid.,

${ }^{45}$ M. Yusuf Hamid kepala desa/ Pak Geuchik desa Meutia Tahun 2019, Langsa, 28 April 2019

${ }^{46}$ Ibid.,

${ }^{47}$ Amarullah, Kaur Pemerintahan desa Meutia Tahun 2019, Langsa, 20 April 2019

${ }^{48}$ Abdullah Ariya, Ketua BPD Desa Alue Beurawe Tahun 2019, Langsa, 17 April 2019

\section{Daftar Pustaka}

Andiny, Puti, JURNAL PENELITIAN EKONOMI AKUNTANSI(JENSI): Analisis Alokasi Dana Desa Terhadap Pembangunan Wilayah di Desa Geudubang Jawa Kecamatan Langsa Baro, VOL. 2, NO.1, JUNI2018.

Anwar, ManajemenPemberdayaanPerempuan, Bandung:Alfabeta, 2007.

Azwardi, Sukanto, Efektifitas Alokasi Dana Desa (Add) Dan Kemiskinan Di Provinsi Sumatera Selatan,Jurnal Ekonomi Pembangunan, Volume 12, No. 1 (Juni 2014).

Cristenson, James A., Jerry W. Robinson, Community development in perspective, Jr Ames: Ioa State Univercity Press, 1989.

Daryanto, Kamus Indonesia Lengkap, Surabaya: Apollo, 1997.

Departemen Agama RI AlQur'an PT. Syaamil Cipta Media: Bandung,2005. Al-Qur'an dan terjemahnya Q.S: Ar-Ra'd (13) ayat 11, PT Syaamil Cipta Media, Bandung, 2005.

Ife, J.W, Community Development: Creating Community Alternatives-vision, Analisys and Practice, (Melbourne:Longman, 2000.

Kamus Besar Bahasa Indonesia, Pusat Bahasa Departemen Pendidikan Nasional, Jakarta, Pusat Bahasa, 2008.

Kuncoro, Mudrajad, Dasar-dasar Ekonomi Pembangunan,Yogyakarta: UPPSTIM YKPN, 2010

Machendrawati, Nanih, Agus Ahmad Safei, Pengembangan Masyarakat Islam dari Ideologi, Strategi, sampai Tradisi. Bandung: PT Remaja Rosdakarya, 2001.

Manulang, M., Dasar-Dasar Manajemen, Jakarta: Ghalia Indonesia, 1990.

Pasal 9 Peraturan Menteri Desa, Pembangunan Daerah Tertinggal danTransmigrasi Nomor 5 Tahun 2015 tentang Penetapan Prioritas Penggunaan Dana Desa Tahun 2015. 
276 AT-TAWASSUTH: Jurnal Ekonomi Islam, Volume IV No. 2 Juli Desember 2019: 252 - 276

Putra, Chandra Kusuma, Ratih Nur Pratiwi, Suwondo, Pengelolaan Alokasi Dana Desa dalam Pemberdayaan Masyarakat Desa, Malang, Jurnal Administrasi Publik, 2014.

Sholeh, Chabib, Heru Rochansjah, Pengelolaan Keuangan Desa, Bandung: FOKUS MEDIA, 2015.

Soekanto, Soerjono, Pengantar Penelitian Hukum, Jakarta: Rineka Cipta,1986.

Soetomo, Strategi-strategi Pembangunan Masyarakat, Yogyakarta: Penerbit Pustaka Pelajar, 2006.

Suharsimi, Arikunta, Pengelolaan Kelas Dan Siswa, Jakarta: CV. Rajawali,1988.

Suharto, Edi. Membangun Masyarakat Memberdayakan Masyarakat. Cetakan III. (Bandung: PT Refika Aditama, 2009.

Sule, Erni Tisnawati, Kurniwan Saefullah, pengantar manajemen, Jakarta: Kencana Perdana Media Goup, 2009.

Sutoro, et.Al. Dana Desa Untuk Membangun Indonesia, Tanya Jawab Seputar Dana Desa). Kementrian Desa, Pembangunan Daerah Tertinggal, dan Transmigrasi. Jakarta, 2016.

Syafrudin, Ateng dan Na'a, Suprin. Pergulatan Hukum Tradisional dan Hukum Moderen Dalam Desain Otonomi Desa. P.T. Alumni, Bandung; 2010.

Zubaedi, Pengembangan Masyarakat: Wacana dan Praktik, Jakarta: Kencana, 2014. 